\title{
Impacts of timber forwarding on physical properties of forest soils in southern Finland
}

\section{Toivio, Jenny Helena}

2017-12-01

Toivio , J H , Helmisaari , H-S M , Palviainen , M M , Lindeman , H , Ala-llomäki , J , Sirén , M \& Uusitalo , J 2017 , ' Impacts of timber forwarding on physical properties of forest soils in southern Finland ' , Forest Ecology and Management, vol. 405 , pp. 22-30 . https://doi.org/10.1016/j.foreco.2017.09

http://hdl.handle.net/10138/309148

https://doi.org/10.1016/j.foreco.2017.09.022

cc_by_nc_nd

acceptedVersion

Downloaded from Helda, University of Helsinki institutional repository.

This is an electronic reprint of the original article.

This reprint may differ from the original in pagination and typographic detail.

Please cite the original version. 

Jenny Toivio ${ }^{1 *}$, Heljä-Sisko Helmisaari ${ }^{1}$, Marjo Palviainen ${ }^{1}$, Harri Lindeman², Jari Ala-llomäki ${ }^{3}$, Matti Sirén $^{3}$, Jori Uusitalo ${ }^{2}$

${ }^{1}$ University of Helsinki, Department of Forest Sciences, P.O. Box 27, Fl-00014 Helsinki

62 The Natural Resources Institute Finland, Green Technology Unit, Korkeakoulunkatu 7, FI-37200 Tampere ${ }^{3}$ The Natural Resources Institute Finland, Green Technology Unit, Koetilantie 5, FI-00790 Helsinki

$8 \quad{ }^{*}$ Corresponding author: E-mail address: toiviojenny@gmail.com

9

10

11

12

13

14

15

\section{Abstract}

Forest harvesting activities can cause soil damage and disturbance through soil compaction, rut formation and soil mixing. These affect the soil structure and functions and forest productivity. Soil compaction results for instance in increased bulk density and decreased porosity, affecting soil moisture, water infiltration and aeration. The effects of timber forwarding on soil physical properties have gained little attention in boreal forests. These issues will become more important in the future since harvesting operations on unfrozen soils are getting more common due to the anticipated climate warming.

In this study, the changes of forest soil physical properties (bulk density, moisture content and porosity) after 1 to 10 forwarder passes on two fine-grained mineral soil sites in southern Finland were analysed. Penetration resistance and rut formation were also measured. The measurements were performed in three periods with different soil moisture conditions. The test drives were carried out with a conventional 8-wheeled forwarder with total mass of 29.8 tons.

Soil bulk density increased and porosity decreased after the machinery passes. However, soil moisture content increased on one site and mainly decreased on another. The first three passes caused the greatest compaction and rutting, the first pass having the strongest impact. After the first and third pass $34-55 \%$ and over $70 \%$ of the total mean rut depth was formed, respectively. Further passes only had slight effects. The compaction and changes of soil physical properties appeared to be greater in dry conditions. Rut formation and soil mixing 
were greater in moist conditions. The results are, however, site-specific, and more research is needed to achieve a better understanding of the relationships between different factors affecting impacts of timber forwarding on soil.

\section{Highlights}

- Traffic by heavy machinery has significant impacts on soil properties

- First passes cause the strongest impacts

- Impacts depend highly on soil characteristics and actual site conditions

\section{Keywords}

timber harvesting, soil damage, soil compaction, soil protection, rut formation

\section{Introduction}

Soil is one of the most important components in ecosystems, providing key services such as production of biomass and energy. It is also a key component of carbon, nutrient and water cycles and gas exchange. However, soil is usually not an object of specific protection objectives and targets and is rather brought indirectly in connection with activities aimed at the protection of air, water or vegetation (EUA, 2002). In recent decades, however, soil has gained more importance, social visibility and attention. The European Union published in 2016 a report on the implementation of the Soil Thematic Strategy, which was adopted already in 2012 (European Commission, 2016). The United Nations declared 2015 as the International Year of Soils with the aim to raise awareness on the importance of healthy soil (European Commission, 2014). Sustainable soil management practices, soil protection and preservation are essential for food security, water quality and plant production.

The concern of tree and soil disturbances through forest operations with bigger, heavier and more powerful machines has grown in the past decades (e.g. Ala-llomäki et al., 2011; Hartanto et al., 2003; Jansson and Johansson, 1998; Rohand et al., 2004). Forest operations and mechanical stress can result in serious and prolonged changes in soil, affect soil functions and properties, reduce soil and forest productivity and eventu- 
ally cause financial losses (e.g. Elliot et al., 1999; Jansson and Johansson, 1998; Lüscher et al., 2010; Sutherland, 2003). In recent years there has been an increasing interest in sustainable forest management, and a detailed review of the available literature on machinery-induced negative effects on forest soils is provided by Cambi et al. (2015).

Mechanized harvesting and terrain transport have been reported to cause multiple impacts such as soil compaction, rut formation, changes in soil micro climate, stem damage, reduced tree and root growth, increased soil erosion, vulnerability to fungus infections and loss of biodiversity, organic matter, value and volume of trees (e.g. Bygden et al., 2004; Demir et al., 2007; Elliot et al., 1999; Marshall, 2000; Nugent et al., 2003; Sirén et al., 2013). Soil compaction is of high importance because of its effects on soil functions, processes and properties. For instance, it increases the soil bulk density and shear strength, modifies the pore system and soil structure and decreases soil moisture content, porosity, water and air infiltration, respiration and gas exchange (e.g. Bagheri et al., 2012; Jansson and Johansson, 1998; Marx et al., 2013; Nugent et al., 2003; Rohand et al., 2004; Susnjar et al., 2006). In addition, the absorption of nutrients and water by trees and other vegetation are negatively affected in compacted soil (Susnjar et al., 2006; Rohand et al., 2004).

Soil bearing strength is one of the most important characteristics for the quality of ground usability (Susnjar et al., 2006). It indicates the capacity of the soil to resist external forces and affects the trafficability, production efficiency and damages caused by timber haulage (Susnjar et al., 2006). Soil strength and vulnerability to compaction are mainly influenced by its moisture content and particle size distribution (e.g. Lüscher et al., 2010; Marx et al., 2013; Susnjar et al., 2006). Also other factors, such as coarse roots, can increase the bearing capacity of soil. Thus, soils with high moisture content, fine textured soils and peatlands are sensitive to soil damage and compaction (e.g. Marx et al., 2013; Nugent et al., 2003; Sirén et al., 2013; Spoor et al., 2003; Uusitalo and Ala-Ilomäki, 2013; Zeleke et al., 2007). The most fertile spruce stands are located on moist and fine-grained soils with a low bearing capacity (Eliasson and Wästerlund, 2007). Also, as spruce horizontal roots are superficial, these stands are especially vulnerable to logging damage (Sirén et al., 2013).

Frozen soil has a better bearing strength, which ensures more efficient harvesting and causes less soil disturbance (Susnjar et al., 2006; Sutherland, 2003). In Finland, up to $60 \%$ of logging is carried out between October and March, when the soil is frozen (Sirén et al., 2013). However, due to the anticipated climate warming and increasingly mild winters a greater proportion of logging needs to be carried out while the soil is not frozen, which may increase the risk for soil disturbances. Whether dry and warm autumn or mild winter with 
little snow and frost but high soil moisture content would be a more suitable season for Norway spruce thinning has been brought up by Sirén et al. (2013).

The greatest impact of machinery traffic occurs direct in the extraction trails, after the first passes and in the uppermost soil $(0-10 \mathrm{~cm})$ (e.g. Coder, 2007; Elliot et al., 1999; Froehlich and McNabb, 1983; Jakobsen and Greacen, 1985; Naghdi et al., 2007; Rab, 2004). However, influences in nearby areas and in deeper soil layers, at more than $80 \mathrm{~cm}$ depth, are also reported (e.g. Ampoorter et al., 2007; Jakobsen and Greacen, 1985; Lüscher et al., 2010; Naghdi et al., 2007). Furthermore, the forwarder has a greater impact and is a greater threat to soil than the harvester (Kremer and Schardt, 2007; Surakka and Sirén, 2007).

The level of soil and root damage depends mostly on the mass and load of vehicles as well as on soil and site characteristics such as soil type, texture, structure, moisture, content of organic matter and slope. Other affecting factors include machine equipment (tyres, tracks, chains), speed, number of machinery passes, logging method, timing and planning of activity and skillness of on-site personnel (e.g. Demir et al., 2007; Jansson and Johansson, 1998; Kremer et al., 2012; Naghdi et al., 2007; Susnjar et al., 2006).

Soil is a limited, non-renewable resource as it takes up to thousands of years for one centimeter of soil to form and once the soil is damaged, it can take years to recover (European Commission, 2015; HBS, 2015). Soil regeneration is a long process, and it is mainly limited to the top $15 \mathrm{~cm}$ (Susnjar et al., 2006). Top soil regeneration time after skidding activities differs from 10 to over 30 years, and even up to irreversibility (e.g. Croke et al., 2001; Froehlich and McNabb, 1983; Lousier, 1990; Rab, 2004). Especially in the deeper soil layers, influences of compaction are very long-term (Alakukku et al., 2003; Sakai et al., 2008). Maintaining the soil in a healthy state is essential for ensuring a stable environment for forest flora and fauna (Sutherland, 2003).

A great deal of research has been conducted on technological and biological issues of timber harvesting in Finland, but hardly any of the work done so far concentrates directly on the pedological approach, i.e. the changes in soil physical properties and the effect of machinery traffic on soil. The aim of this study was to evaluate the effects of heavy machinery traffic on forest soil on two fine textured sites in southern Finland. Soil bulk density, moisture content, porosity and grain size distribution were analysed at two soil depths before and after machinery passes. Rut depth and cone penetration resistance were measured after each pass. The measurements were performed in three periods with different soil moisture conditions in September, November and December 2015. 
- traffic by heavy machinery compacts the soil, which results in increased bulk density and decreased porosity and soil moisture content,

- $\quad$ soil damage, rutting and compaction are greater in moister soil,

- the impacts increase with the number of machine passages,

- the greatest impact to the soil occur after the first passes.

\section{Materials and methods}

\subsection{Study sites}

The study sites were located in Vihti in southern Finland and can be classified as the Oxalis-Myrtillus forest type (Cajander, 1949). These herb-rich heath forests are relatively fertile sites and comprise approx. $29 \%$ of mineral soils in southern Finland (Hotanen et al., 2008). The mean annual temperature is $4.6^{\circ} \mathrm{C}$ and the mean monthly temperatures vary between $-6^{\circ} \mathrm{C}$ in January and February and $17^{\circ} \mathrm{C}$ in July. The mean annual precipitation is $650 \mathrm{~mm}$ with clearly more precipitation during the second half of the year (Pirinen et al., 2012).

Site A (Rintelä) $\left(60^{\circ} 24.6 \mathrm{~N}, 24^{\circ} 23.2 \mathrm{E}\right.$, around $60 \mathrm{~m}$ above sea level) was an even-aged Norway spruce (Picea abies (L.) Karst) stand on a silty-clayey soil with a shallow $(1-5 \mathrm{~cm})$ humus horizon. The relief was an even slope with minor inclination to northwest. The soil was prepared by ploughing before planting approx. 30 years ago and the ploughing furrows are still visible.

Site B (Pervonmäki) $\left(60^{\circ} 24.4 \mathrm{~N}, 24^{\circ} 22.4 \mathrm{E}\right.$, around $70 \mathrm{~m}$ above sea level) was a forest of natural origin with different tree species and age classes. The stand was mostly Norway spruce dominated with a mixture of birch (Betula pendula Roth) and aspen (Populus tremula L.). It was located in a dell and characterised by a siltysandy soil with a variable thickness $(5-20 \mathrm{~cm})$ of organic layer with a shallow peat layer in moist patches. The humus form was moder in both sites.

Five plots of $15 \times 20 \mathrm{~m}$ were established: three on site $\mathrm{A}$ and two on site $\mathrm{B}$. The plots were divided in three test trails $(5 \times 20 \mathrm{~m})$, one for each study period (Sep., Nov., Dec.) (Fig. 1). Each test trail was further divided into four study sections $(5 \times 5 \mathrm{~m})$. The lines were carefully marked on the ground in order to keep the measurement points constant. The maximal amount of machinery passes was 10 , which was always reached except on site B in November as the bearing capacity collapsed due to high soil moisture content after the third pass. 

and soil samples is shown in Table 1 and explained in further chapters.

141

142

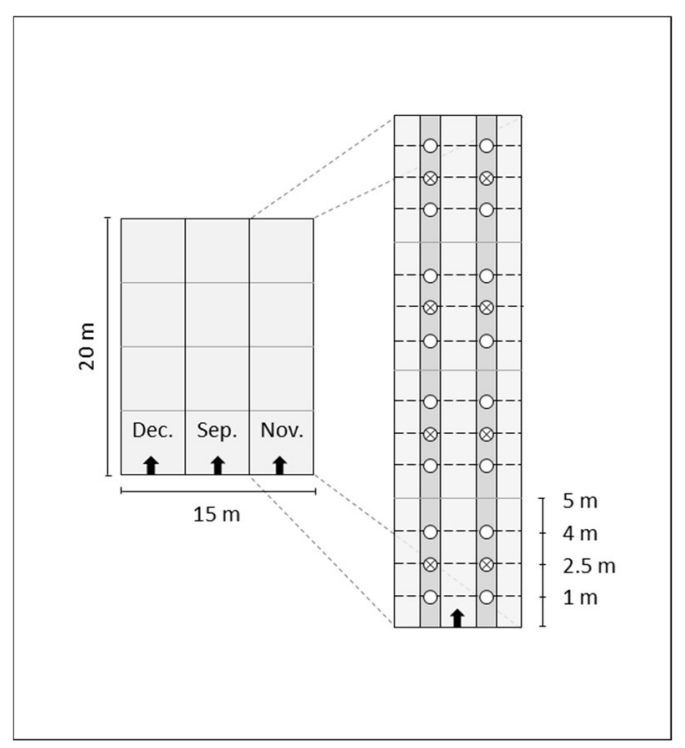

Figure 1. Schematic maps of a study plot with the three test trails (left) and a test trail with the measurement points: (o) cone penetration resistance and rut depth measurement points, (x) soil sample points.

Table 1. Description of the measurements and soil sample collection. *Due to the wet sandy soil on site B, all samples of soil depth 10-20 cm could not be collected: 7 samples in September and 3 in November.

\begin{tabular}{|c|c|c|c|c|c|c|c|c|c|c|c|c|c|c|c|c|c|c|}
\hline \multirow{3}{*}{ Description } & \multicolumn{6}{|c|}{ Rut depth } & \multicolumn{6}{|c|}{ Cone penetration resistance } & \multicolumn{6}{|c|}{ Soil samples } \\
\hline & \multicolumn{3}{|c|}{ Site A } & \multicolumn{3}{|c|}{ Site B } & \multicolumn{3}{|c|}{ Site $\mathrm{A}$} & \multicolumn{3}{|c|}{ Site $B$} & \multicolumn{3}{|c|}{ Site $A$} & \multicolumn{3}{|c|}{ Site $B$} \\
\hline & Sep. & Nov. & Dec. & Sep. & Nov. & Dec. & Sep. & Nov. & Dec. & Sep. & Nov. & Dec. & Sep. & Nov. & Dec. & Sep. & Nov. & Dec. \\
\hline $\begin{array}{c}\text { Measurements on } \\
\text { one test trail }\end{array}$ & 24 & 24 & 24 & 24 & 24 & - & 24 & 24 & 24 & 24 & 24 & - & 8 & 8 & 8 & 8 & 8 & - \\
\hline Number of plots & 3 & 3 & 3 & 2 & 2 & - & 3 & 3 & 3 & 2 & 2 & - & 3 & 3 & 3 & 2 & 2 & - \\
\hline $\begin{array}{l}\text { Number of } \\
\text { passages }\end{array}$ & 10 & 10 & 10 & 10 & 3 & - & & & & & & & & & & & & \\
\hline $\begin{array}{c}\text { Number of } \\
\text { measurements } \\
\text { (before and after } \\
\text { all passes) }\end{array}$ & & & & & & & 2 & 2 & 2 & 2 & $\begin{array}{c}1 \\
\text { (only } \\
\text { before) }\end{array}$ & - & 2 & 2 & 2 & 2 & $\begin{array}{c}1 \\
\text { (only } \\
\text { before) }\end{array}$ & - \\
\hline $\begin{array}{c}\text { Number of soil } \\
\text { depths }\end{array}$ & & & & & & & & & & & & & 2 & 2 & 2 & $2^{*}$ & $2^{*}$ & - \\
\hline $\begin{array}{c}\text { Total number of } \\
\text { values }(n)\end{array}$ & 720 & 720 & 720 & 480 & 144 & - & 144 & 144 & 144 & 96 & 48 & - & 96 & 96 & 96 & 57 & 29 & - \\
\hline
\end{tabular}

Both sites were clear-cut before the first measurements in September. The harvesting and processing of the trees were carried out from outside the plots to keep them intact. Harvesting residues were collected and the test trails were placed in order to avoid travelling over stumps, as this inevitably causes uneven weight distribution and soil loading. This succeeded well on site A as the trees were planted in rows. However, on site B the forwarder had to travel over several stumps because of the natural origin of the forest. 
The machinery passes were carried out with an 8-wheeled Ponsse Elk forwarder equipped with Nokia Forest King F2 710/45-26.5 tires, universal Olofsfors EVO tracks on the rear bogie and Superhokki 160 TS chains on the rear wheels of the front bogies. The forwarder was further loaded with $9800 \mathrm{~kg}$ of pulpwood. The total mass was $29800 \mathrm{~kg}$.

\subsection{Measurement of soil properties}

To determine the effects of machinery passes on soil properties, dry soil bulk density (BD), moisture content (VWC - volumetric water content), total porosity and soil particle size distribution were analysed in laboratory.

Soil samples were taken with a core sampler, $500 \mathrm{~mm}$ in height and $25 \mathrm{~mm}$ in diameter, before and after all passes and from every predefined measurement point along the test trail (see Fig. 1). In December a round sampling tube with a diameter of $46 \mathrm{~mm}$ was used. Two mineral soil samples were taken at depths of 0-10 cm and $10-20 \mathrm{~cm}$, in total of 96 samples from site A in each study period (see also Table 1). Sample collection on site B was more difficult due to the wet sandy soil. During the first period 57 samples were taken and during the second period 29 samples were taken before the machine traffic. The thickness of the organic layer was measured in the field.

The VWC was calculated from the difference between the wet and oven-dry soil mass $\left(60^{\circ} \mathrm{C}, 3-6\right.$ days). Soil BD was calculated by dividing the oven-dry soil mass by the wet volume of the sample. Porosity $(\varphi)$ was calculated from BD and density of soil solids (DS) using the formula $\varphi=((D S-B D) / / D S)^{*} 100$, where a DS value of $2.65 \mathrm{~g} / \mathrm{cm}^{-3}$ for mineral matter and a mean value of $1.4 \mathrm{~g} / \mathrm{cm}^{-3}$ for organic matter were used (Hillel, 1982). To estimate the soil particle size distribution, common methods sieving and sedimentation were used (Heiskanen and Tamminen, 1992).

Additionally, three soil profiles were characterized for estimating the soil type and site conditions. Soil samples were taken from A-, B- and C-horizons and the parameters soil particle size distribution, organic matter content, colour and $\mathrm{pH}$ were analysed.

Soil particle size distributions of the test samples can be regarded as silty clay on site A (plots 1-3), whereas it varies between sandy and clay loam on site B (plots 4-5). The distribution for each plot is the mean result from both test depths, which were very similar. The grain size was coarser on site B and there was more variation in grain size and thickness of the soil horizons and the humus layer (Fig. 2). Considering the soil 

of the properties change at this particle size (Heiskanen, 2003). The mean soil particle size shows that the soils on site $A$ and in plot 5 can be defined as fine grained and in plot 4 as coarse grained mineral soils. According to the World Reference Base for Soils (2006) the soils can be categorized as a haplic Gleysol dystric (site A) and a histic Gleysol dystric (site B).



Figure 2. Soil particle size distribution on each plot (site A: plot1-3, site B: plot 4-5).

\subsection{Monitoring of penetration resistance and rut formation}

Cone penetration resistance (CPR) was measured with the Eijkelkamp Penetrologger 0615SA penetrometer consisting of an $80 \mathrm{~cm}$ long rod and a 60-degree cone with a diameter of $11.28 \mathrm{~mm}\left(1 \mathrm{~cm}^{2}\right)$. Depth readings were captured every $1 \mathrm{~cm}$ by an ultrasonic depth sensor. The results were further analysed and means calculated to describe the strength and compaction of the soil. Penetration resistance was measured on both wheel ruts before and after all passes (see also Table 1), but also after every pass in two study sections on each site to define the impact of single passes. As in soil sample collection, measurements were made only before the passes on site B in November as no further measurements were possible and reasonable due to the deep rut formation and soil disturbance.

To measure rut formation a self-levelling construction laser device, a levelling rod and a laser beam detector were used. Before the test drives, a reference height was marked on a tree and a reference height level of the ground was measured for every measurement point to be located on wheel ruts. After each pass the height of 
the rut bottom was determined using the laser beam detector and the levelling rod (see also Table 1). Afterwards the rut depth was calculated by comparing the rut bottom height to the reference height of each measurement point. Furthermore, means of rut depth for each section, plot and site were calculated.

\subsection{Statistical analyses}

A general linear model (GLM) was used to study the relationship of soil bulk density, moisture content and porosity to the treatment (machine passes) and other fixed factors and their interactions. Treatment, site, month (September, November and December) and soil depth (humus, 0-10 cm and 10-20 cm mineral soil) and their interactions were defined as fixed factors in the model. The differences in soil bulk density, moisture content and porosity before and after all machinery passes in each measurement point were tested with pairedsamples t-tests. Differences were considered statistically significant when $P$ was $<0.05$. A linear regression analysis was used to examine the relationship between rut depth, soil bulk density, cone penetration resistance and soil moisture content. Statistical tests were performed using IBM SPSS version 23 (IBM Corp, Armonk, NY, USA).

\section{Results}

\subsection{Soil properties}

Site, month and soil depth significantly affected the soil moisture content (Table 2). It increased from September to November about $10 \%$ on each site, but only slightly from November to December (Fig. 3). On site A the VWC was $21-31 \%$ in September, 33-45 \% in November and 40-48 \% in December. Site B was moister having $30-40 \%$ VWC in September and $42-49 \%$ in November. The deeper soil sample depth $(10-20 \mathrm{~cm})$ was about $5 \%$ moister on site A. Site B had an organic layer up to $20 \mathrm{~cm}$ with higher VWC (up to $58 \%$ in Nov.) and therefore, the VWC was more variable. Soil BD and porosity were significantly affected by treatment, site, month and soil depth (Table 2). The dry soil bulk density was higher and consequently porosity lower in December and at $10-20 \mathrm{~cm}$ depth. Before the test drives, $B D$ ranged overall between $0.8-1.3 \mathrm{~g} / \mathrm{cm}^{3}$ on site $A$ and 1.1-1.6 $\mathrm{g} / \mathrm{cm}^{3}$ on site B and porosities between $50-70 \%$ and $40-55 \%$ respectively. 
There was a significant interaction between treatment and month and between treatment and depth (Table 2), indicating that the machinery passes had different effect on soil BD, porosity and moisture content in different months and at different depths. Greater effects and changes occurred in dry September and at the 0$10 \mathrm{~cm}$ depth than in moister November and December and at the $10-20 \mathrm{~cm}$ depth. Notable changes in humus layer properties were found on site B. As expected, BD increased and porosity generally decreased through machinery passes. However, contrasting results can be observed for the VWC: increases on site A and decreases on site $B$.

There was a significant interaction between site and treatment (Table 2) and the changes in soil properties were statistically significant on site A (Fig. 3). After the machinery passes, BD increased by $45 \%$ at $0-10 \mathrm{~cm}$ depth and by $34 \%$ at $10-20 \mathrm{~cm}$ depth in September. The VWC increased around $28 \%$ and porosity decreased $22 \%$ at both depths. In November BD increased by $32 \%$ at $0-10 \mathrm{~cm}$ depth and by $7 \%$ at $10-20 \mathrm{~cm}$ depth. The corresponding values in December were $17 \%$ and $4 \%$, respectively. The VWC increased almost $20 \%$ at $0-10 \mathrm{~cm}$ depth, but remained rather unchanged at $10-20 \mathrm{~cm}$ depth during both last periods. Porosity was 16 $\%$ and $6 \%$ lower in November and $11 \%$ and $4 \%$ lower in December after the test driving.

The results between the plots on site A were similar, but the results for the two plots on site B were mostly opposite and will therefore not be discussed further as mean values. There were significant changes only for the humus measurements and VWC in plot 5. These significant results have the same trend as for site A with the exception of VWC in plot 5 . In plot $4, \mathrm{BD}$ increased by $31 \%$ at the upper depth and by $13 \%$ at the lower depth, whereas in plot 5 it decreased $18 \%$ and $11 \%$, respectively. Consequently, porosity decreased around $20 \%$ in plot 4 and increased about $17 \%$ in plot 5 at both depths. The VWC decreased at the upper depth around $20 \%$ in both plots, but at the lower depth after all passes it was $7 \%$ lower in plot 4 and $15 \%$ higher in plot 5 .

Table 2. The relationship of soil moisture content, bulk density and porosity to the machinery passes (treatment) and other fixed factors and their interactions in a general linear model (GLM). 


\begin{tabular}{|c|c|c|c|c|c|c|c|c|c|}
\hline & \multicolumn{3}{|c|}{ Moisture content } & \multicolumn{3}{c|}{ Bulk density } & \multicolumn{3}{c|}{ Porosity } \\
\cline { 2 - 10 } & $\begin{array}{c}\text { Degrees of } \\
\text { freedom }\end{array}$ & F-value & $\begin{array}{c}\text { Significance, } \\
\mathrm{p} \text {-value }\end{array}$ & $\begin{array}{c}\text { Degrees of } \\
\text { freedom }\end{array}$ & F-value & $\begin{array}{c}\text { Significance, } \\
\mathrm{p} \text {-value }\end{array}$ & $\begin{array}{c}\text { Degrees of } \\
\text { freedom }\end{array}$ & F-value & $\begin{array}{c}\text { Significance, } \\
\mathrm{p} \text {-value }\end{array}$ \\
\hline Intercept & 1 & 14294.07 & $<0.001$ & 1 & 13006.12 & $<0.001$ & 1 & 17888.35 & $<0.001$ \\
\hline Site & 1 & 11.17 & 0.001 & 1 & 72.91 & $<0.001$ & 1 & 59.02 & $<0.001$ \\
\hline Treatment & 1 & 1.36 & 0.244 & 1 & 97.55 & $<0.001$ & 1 & 141.84 & $<0.001$ \\
\hline Month & 2 & 238.59 & $<0.001$ & 2 & 13.66 & $<0.001$ & 2 & 11.06 & $<0.001$ \\
\hline Depth & 2 & 27.56 & $<0.001$ & 2 & 317.88 & $<0.001$ & 2 & 95.19 & $<0.001$ \\
\hline Site * Treatment & 1 & 39.55 & $<0.001$ & 1 & 33.82 & $<0.001$ & 1 & 27.37 & $<0.001$ \\
\hline Site * Depth & 1 & 8.46 & 0.004 & 1 & 2.07 & 0.151 & 1 & 1.68 & 0.196 \\
\hline Treatment* Month & 2 & 4.23 & 0.015 & 2 & 14.95 & $<0.001$ & 2 & 12.1 & $<0.001$ \\
\hline Treatment * Depth & 2 & 7.46 & 0.001 & 2 & 12.3 & $<0.001$ & 2 & 34.81 & $<0.001$ \\
\hline Month * Depth & 2 & 0.22 & 0.8 & 2 & 0.71 & 0.493 & 2 & 0.57 & 0.564 \\
\hline Site * Treatment * Depth & 1 & 5.5 & 0.02 & 1 & 0.02 & 0.903 & 1 & 0.01 & 0.913 \\
\hline Site * Month * Depth & 2 & 3.26 & 0.04 & 2 & 2.02 & 0.134 & 2 & 1.64 & 0.196 \\
\hline
\end{tabular}

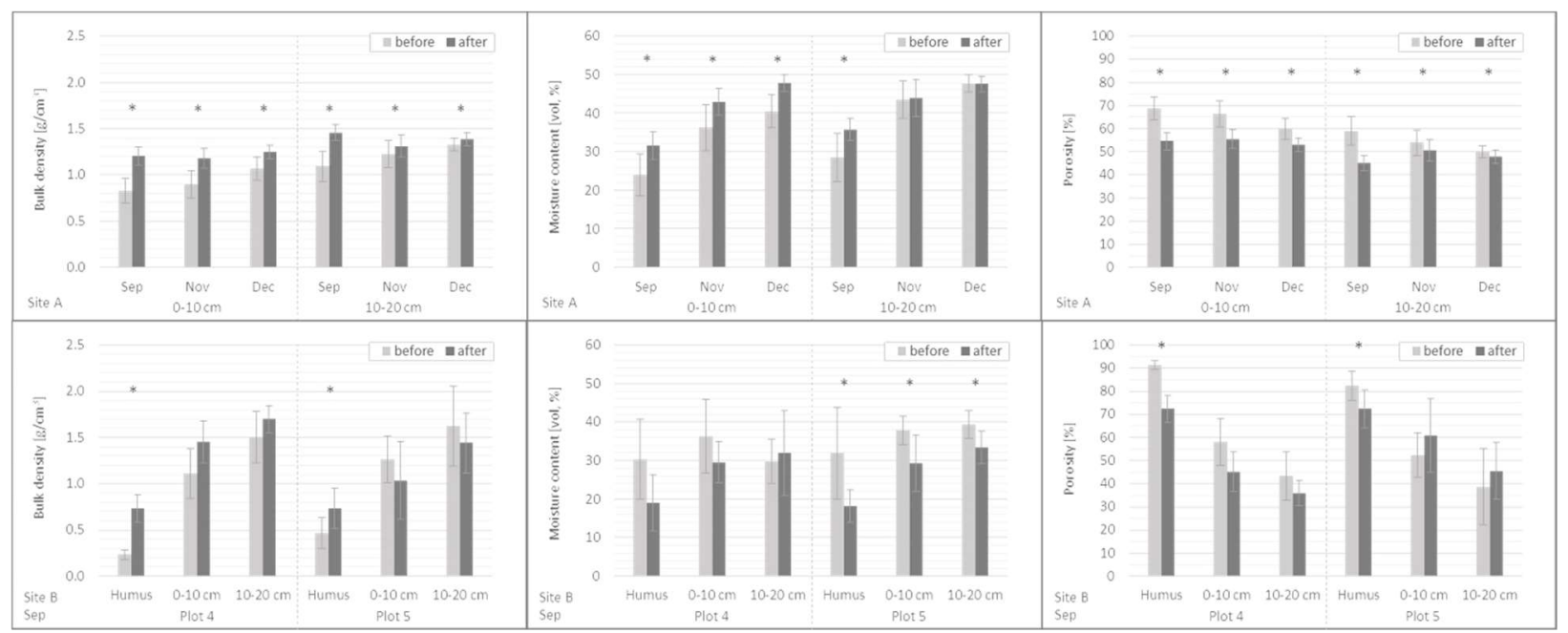

254 Figure 3. Soil bulk density, moisture content and porosity measurements before and after all machinery 255 passes on site A (all test periods) and site B (September). ${ }^{*} P<0.05$.

258 The CPR measurements had higher values and greater compaction in dry September than in moister Novem259 ber and December (Fig. 4). Penetration resistance and soil compaction were thus clearly lower in moist con260 ditions. The greatest changes occurred in the top $60 \mathrm{~cm}$ soil depth. In September, CPR was 0.5-1.5 MPa 261 higher in the first $40-50 \mathrm{~cm}$ soil depth on site $A$ and between $30-50 \mathrm{~cm}$ soil depth on site $B$ after the machinery 262 passes. In contrast, the results for November and December showed decreased values after passing. The overall level of CPR was, however, clearly lower than in September. The first three passes had the greatest 
impact on the top soil of about $30 \mathrm{~cm}$, whereas the further passes caused compaction at greater depths, especially in moist conditions (not shown).

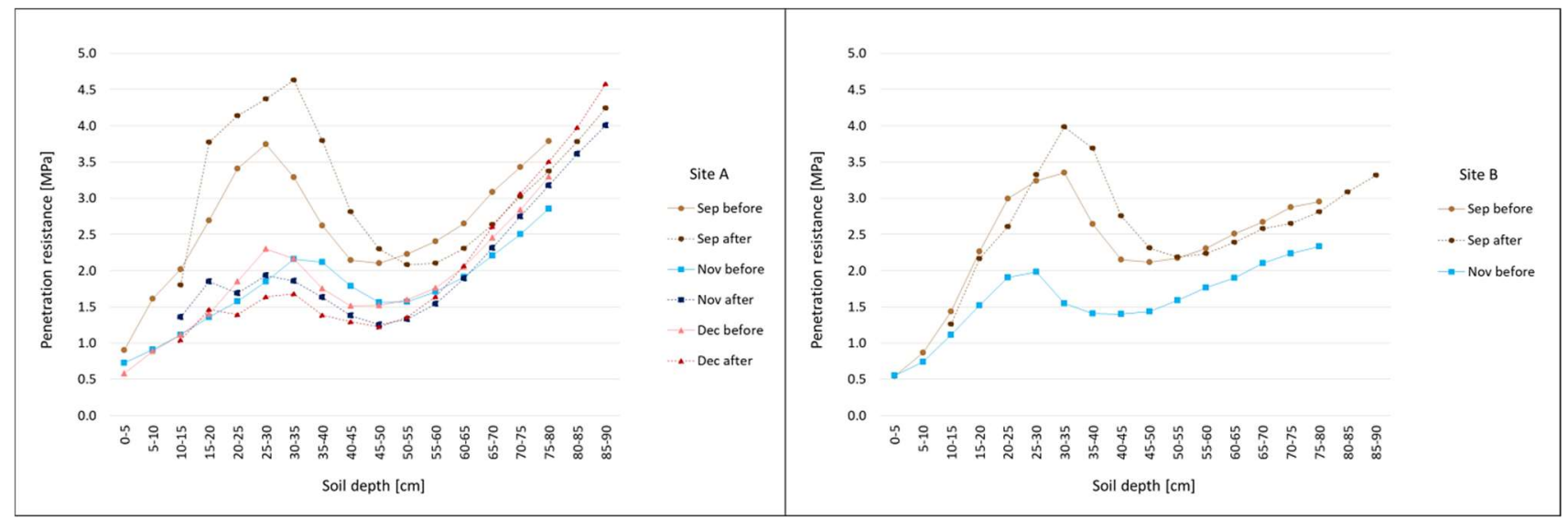

Figure 4. Mean penetration resistance before and after the test drive on site $\mathrm{A}$ and $\mathrm{B}$. Measurements after the test drives are represented with a correction of $10 \mathrm{~cm}$ according to the approx. mean rut depth.

In contrast to CPR, rut formation followed a clear pattern in moist conditions (Fig. 5, Table 3). In the silty clay soil on site $\mathrm{A}$ there were minor differences between the study periods, while in the sandy clay loam soil on site B deep ruts were formed in November. The mean rut depth after all passes on site A was $9 \mathrm{~cm}$ in September and approx. $13 \mathrm{~cm}$ in November and December, rutting being only less than $1 \mathrm{~cm}$ greater in December. On the other hand, VWC had a strong influence on rutting on site B. In September, the mean rut depth was 12 $\mathrm{cm}$, but in November the bearing capacity of the soil collapsed after the initial passes, the mean rut depth being nearly $25 \mathrm{~cm}$ after only three passes.

Rut depth increased almost linearly after each test drive. The greatest rutting and strongest effect occurred after the first machinery passes, whereas the further passes had a minor impact. On site A the rut depth of approx. $4.5 \mathrm{~cm}$ (all periods) and on site B $6.5 \mathrm{~cm}$ (September) and $9 \mathrm{~cm}$ (November) was measured after the first pass. The following passes increased the rut depth by $1-2 \mathrm{~cm}$, but after the fourth pass in September and the sixth pass in November and December the increase was less than $1 \mathrm{~cm}$. However, in moist conditions the further passes caused more rutting. The mean final rut depth in September on site A was exceeded after 5-7 passes in November and December. On site B in November each pass caused rutting of 7-9 cm. Except for the test on site B in November, 34-55 \% of the total mean rut depth was formed after the first pass, 47-66 \% after the second and $72-86 \%$ after the fifth pass (Table 3 ). 




Figure 5. Rut depths after each test drive on both sites.

Table 3. Rut depth values.

\begin{tabular}{|c|c|c|c|c|c|}
\hline \multirow{2}{*}{ Number of passages } & \multicolumn{5}{|c|}{ Mean rut depth [\%] } \\
\cline { 2 - 6 } & Sep & Nov & Dec & Sep & Nov \\
\hline & 49 & 35 & 34 & 55 & 36 \\
\hline 1 & 61 & 48 & 47 & 66 & 70 \\
\hline 2 & 74 & 57 & 56 & 73 & 100 \\
\hline 3 & 86 & 73 & 72 & 86 & \\
\hline 5 & 96 & 86 & 84 & 92 & \\
\hline Mean final rut depth $(\mathrm{cm})$ & 9.2 & 13.1 & 13.4 & 11.9 & 24.7 \\
Range of rut depth $(\mathrm{cm})$ & $4-14$ & $3-18$ & $8-18$ & $0-21$ & $0-38$ \\
\hline
\end{tabular}

\subsection{Statistical analysis}

293 Linear regression analyses were estimated between the variables BD, VWC and CPR measured before the 294 passing in September and November. The mean rut depth after passes was also analysed against VWC before 295 the passes. All measurements were calculated and compared with the corresponding soil sample depths of 0$10 \mathrm{~cm}$ and $10-20 \mathrm{~cm}$.

297 Correlations among the parameters were stronger on site A than on site B (Fig. 6). WWC had a strong positive correlation with $\mathrm{BD}(53 \%)$, whereas with CPR the correlation was negative and rather moderate (33\%). On 
site B, VWC did not correlate with BD (3\%) and only moderately with CPR $(24 \%)$. The relationship between $\mathrm{BD}$ and CPR was $53 \%$ on site $A$ and $14 \%$ on site $B$ (not shown).

However, VWC explained $48 \%$ on site A and $43 \%$ on site B of the variation in rut depth. Thus, increased soil moisture content caused deeper and increased rutting. This could also be well observed on site B, where deep ruts formed and a lot of soil mixing occurred in November (Fig. 7).

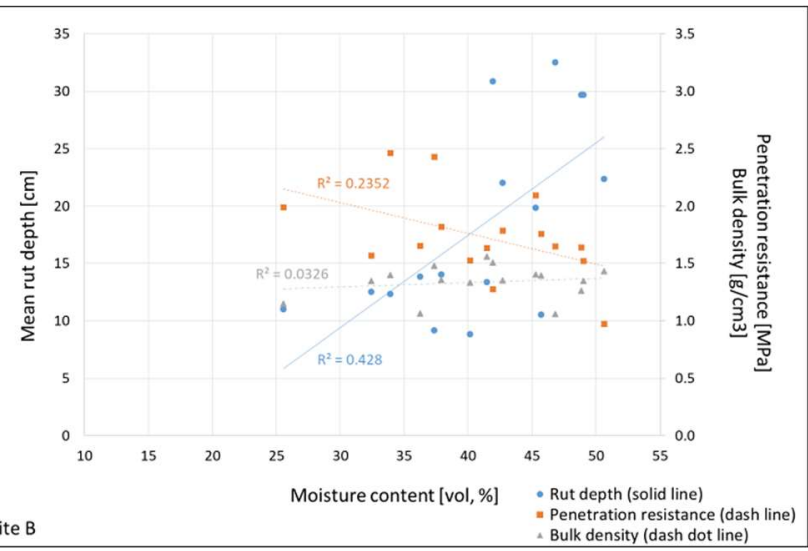

Figure 6. Relationships between bulk density, penetration resistance, rut depth and moisture content on site
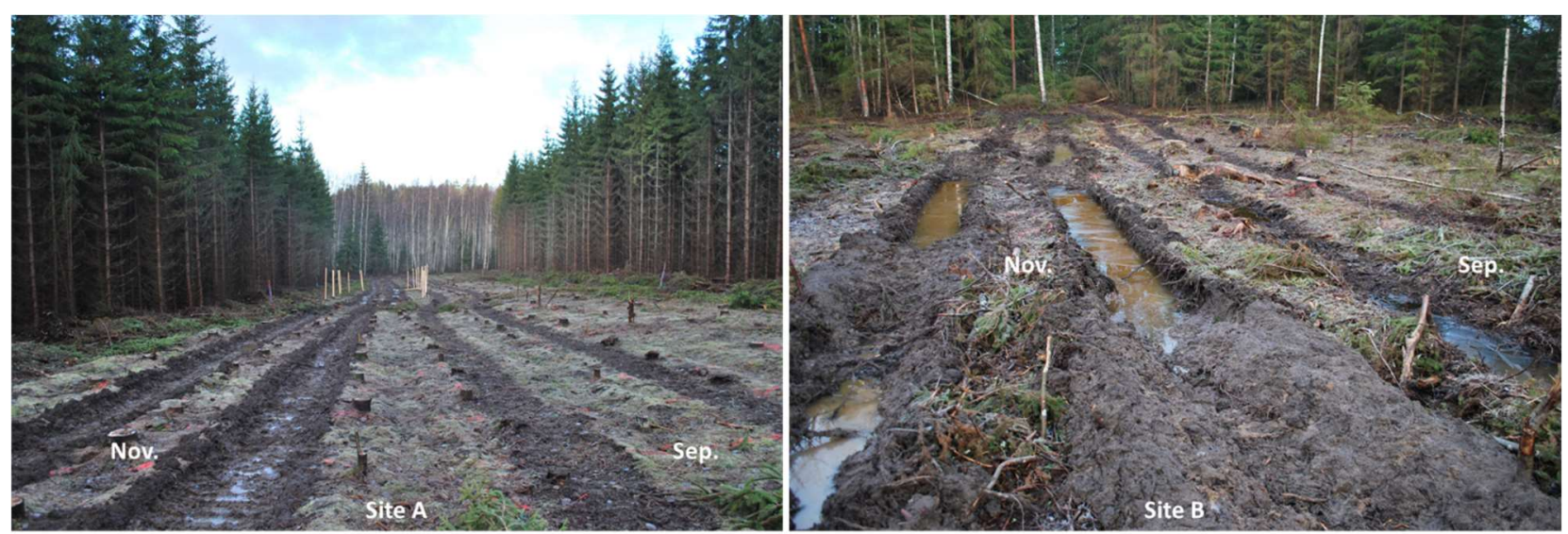

Figure 7. Test trails after the machinery passes in September and November on both sites.

\section{Discussion}

312 We found that BD generally increased after trafficking, which is consistent with previous observations (e.g. 313 Froehlich and McNabb, 1984; Klaes et al., 2016; Naghdi et al., 2016). However, the traffic-induced increase in 314 BD was lower in moist conditions. Similar results were observed for the CPR measurements: the CPR values 
increased in dry conditions, whereas also decreased values were measured in moist conditions. Some researchers, e.g. Braunack (1986), Lenhard (1986) and Jakobsen and Greacen (1985) also reported on decreased CPR and BD values after trafficking. This phenomenon might be due to the higher organic material content of samples from trafficked soil as the organic matter mixes into the mineral soil through trafficking (Jansson and Johansson, 1998; Lenhard, 1986). An alternative explanation can be the loss of thixotropic strength in soil or the increase in soil moisture content to near saturation, which would have rendered the soil non-compactable (Jakobsen and Greacen, 1985). However, the decreases are presumed to be temporary. Jansson and Johansson (1998) found that repeated measurements 14 months after trafficking showed a statistically significant increase in CPR in trafficked plots compared with untrafficked control areas. Furthermore, the measured correlation between BD and CPR on site A corresponds to the 50-60 \% correlation as stated for all soils by Coder (2007).

The porosity measurement was calculated from the BD and therefore the results are related. Porosity generally decreased due to the trafficking, with the same exceptions as in BD. Decrease of soil porosity is a common effect following machinery passing as found in many studies, e.g. Bagheri et al. (2012), Demir et al. (2007), Jakobsen and Greacen (1985), Jansson and Johansson (1998), Susnjar et al. (2006).

The effect of machinery passes on hydrological soil properties are dependent on site characteristics. In this study the VWC showed increased (site A) and decreased (site B) values after trafficking. A decrease of VWC has been commonly reported (e.g. Demir et al., 2007; Susnjar et al., 2006), but also increased values have been measured as the result of passing (e.g. Klaes et al., 2016; Eliasson and Wästerlund, 2007). Huang et al. (1996) found both effects on hydraulic properties. Wronski and Murphy (1994) reported that an increase in the water content could be possible due to trafficking on some sub-plastic clay soils. However, machinery passing causes structural changes in the soil, which leads to a decrease in soil water potential and reduction in air permeability (Wronski and Murphy, 1994).

According to the common recommendations for forestry practice, a rut depth of $10 \mathrm{~cm}$ is permitted (Lüscher et al., 2010; MMM, 2014; Äijälä et al., 2014). In Finland it has been further specified with the maximum proportion of deep ruts $(>10 \mathrm{~cm}$ ) being $4 \%$ of the total length of strip roads (MMM, 2014; Äijälä et al., 2014). The limit of $10 \mathrm{~cm}$ rut depth was reached at the latest after five passes on each site and period, except on site $A$ in September. As in many other reported studies, the initial (1-3) passes caused the greatest rutting (e.g. Jakobsen and Greacen, 1985; Klaes et al., 2016; Naghdi et al., 2016; Susnjar et al., 2006). 
Lüscher et al. (2010) classified strip roads in three categories according to the soil damage after trafficking. Type 1 shows a slight, elastic impact on soil and ruts of under $10 \mathrm{~cm}$, but largely undamaged soil. Type 2 has a greater impact with plastic deformation, low rut side formations and deeper ruts, which are however mostly under $10 \mathrm{~cm}$. In this case the soil damage is not yet severe. In type 3 trafficking causes the formation of deep ruts $(>10 \mathrm{~cm})$ and high rut side formations as well as compaction and serious damage into the top and sub soil. Therefore, the soil suffers from long-term damage and is also ecologically negatively affected (Meyer et al., 2011). From a soil protection perspective, this demonstrates a loss and alteration of soil functions, properties and structures, which is a clear evidence on soil damage and a violation of the principles of sustainability (Kremer et al., 2012).

The test tracks in the present study can be categorised in various manners, depending on the site and the trafficking month. September tracks on site A can be classified into type 1 and November and December into type 2. On site B trafficking caused a greater impact (see Fig. 7). In September, it was classified into type 2, while in November the damage corresponded clearly type 3. Even though VWC on site A in December was close to VWC values of site B in November, soil bearing capacity was not exceeded. Based on this, we conclude that it is very relevant and important to evaluate different factors and site characteristics while estimating effects of harvesting operations.

It has been well established that a thawed fine-grained soil with high VWC results in low bearing capacity, while similar soil in frozen condition has a high bearing capacity (Shoop, 1993; Susnjar et al., 2006). This is also one reason why harvesting operations are traditionally carried out in the winter time on frozen soils with a snow cover protecting the ground from direct contact. Trafficking on wet soils should be avoided as soil disturbance and rut formation are greater than in dry conditions. When all soil pores are filled with water, the soil is saturated. Near the saturation point, the cohesive forces break and the soil loses its bearing capacity. This point was reached on site B in November, when VWC was near $50 \%$. Consequently, the bearing capacity was very low, and deep ruts were formed. According to Miller and Sirois (1986) all moderately deep soils with finer than a sandy loam with clay subsoil (as on site B) have a very high potential for rutting und compaction and are generally the most severely disturbed in logging in wet conditions. However, only slight differences between the test periods were found on site A (see also Fig. 7). Even though VWC was high, the bearing capacity was not exceeded as on site B. This might be due to soil type and site characteristics. It can thus be concluded that the effects of trafficking are highly site-specific and depend on actual site and weather conditions. 
Through optimised prevention, economical, biological and pedological losses, high costs of aftercare as well as soil and tree damages and disturbances can be avoided. Depending on site characteristics and timing, different methods can be applied. Recommendations for best practices to limit soil damage have been well summarized by Cambi et al. (2015). For example, protective harvesting methods e.g. slash cover and reinforcements have been widely recommended to reduce the direct impact of machinery passes (e.g. Eliasson and Wästerlund, 2007; McDonald and Seixas, 1997; Sirén et al., 2013). Furthermore, careful planning, timing, professionality, high level of expertise and care taken by the on-site personnel are very important (e.g. Edlund, 2012; Kremer et al., 2012; Sutherland, 2003). Additionally, models and prediction methods are being developed to predict and lower the risk for soil and tree damages, and to help the planning of forest activities. For example, Zeleke et al. (2007) have established a Pressure-Sinkage-model for prediction of potential site damage by timber harvesting and extraction machinery traffic. In the Natural Resources Institute Finland, a model is being developed, which aims to forecast the soil bearing capacity and rutting risk based on various environmental factors and actual weather conditions. The increasing digitalisation and development of remote sensing methods also bring many alternatives and benefits, especially for the planning of forest activities.

Finally, we conclude that soil damage and rut formation were greater in moister soil as expected, whereas CPR results showed greater compaction in dry conditions. The impacts also increased with the number of machine passages, though the greatest impact to the soil occurred after the first passes as hypothesized. The results for increased bulk densities and decreased porosities were significant. However, the results for the changes in moisture content do not completely confirm our hypothesis as decreased and increased values were measured.

\section{Conclusions}

Harvesting and heavy machinery operations are connected with negative influences on soil. These should be considered in a wider context, since the damages from harvesting operations cannot be completely avoided. Nevertheless, these should be minimized where possible.

The results of this study show clear impacts and changes in the measured parameters due to the forest machinery passing. However, the effects vary depending on the site conditions and the soil properties such as soil type and moisture content. The soil damage can be described mainly as not severe on site $\mathrm{A}$, whereas 
severe damage occurred on site B with VWC near saturation. According to the laboratory analysis, the machinery passing caused a minor impact on BD, VWC and porosity in moist conditions. The CPR measurements showed greater soil compaction in dry soil conditions, whereas deeper ruts formed in moist conditions. The impact of machinery passing was greater on top soil and after the first three passes.

Based on our results, we suggest that research for defining critical limits on the pedological and biological aspects of harvesting is needed for a better understanding of the environmental interactions and relationships. As concluded by Schoenholtz et al. (2000), for the assessment of sustainability in forestry activities, knowledge of forest soil properties has to be extended in order to predict the dynamic behaviour of soil processes and the effects of management practices on these processes. Through increasing information of machinery-induced effects on forest soils, more detailed management strategies, practical guidelines and vulnerability classification could be provided as there are for arable lands (e.g. Alakukku et al., 2003; Chamen et al., 2003; Spoor et al., 2003). More comprehensive studies in different locations and conditions need to be carried out. Further development of research methods and soil and tree protective harvesting are also necessary.

\section{Acknowledgements}

This study is based on an M.Sc. thesis of the corresponding author. The driving tests were done under the research project "Enhancing timber harvesting on sensitive sites", carried out at the Natural Resources Institute Finland. The authors are grateful to Marjut Wallner at the University of Helsinki, Department of Forest Sciences for guidance in the laboratory analyses and to the laboratory staff of the Natural Resources Institute Finland for particle size analysis. We also thank Metsä Group and the personnel of Metsäkoneurakointi Pekka Liiri Oy for their cooperation. The support by Maj and Tor Nessling foundation is gratefully acknowledged.

\section{References}

Ala-llomäki J., Högnäs, T., Lamminen, S., Sirén, M., 2011. Equipping a Conventional Wheeled forwarder for peatland operations. Int. J. For. Eng. 22 (1), 7-13. 
Alakukku, L., Weisskopf, P., Chamen, W.C.T., Tijink, F.G.J., van der Linden, J.P., Pires, S., Sommer, C., Spoor, G., 2003. Prevention strategies for field traffic-induced subsoil compaction: a review. Part 1. Machine/soil interactions. Soil Till. Res. 73, 145-160.

Ampoorter, E., Goris, R., Cornelis, W.M., Verheyen, K., 2007. Impact of mechanized logging on compaction status of sandy forest soils. For. Ecol. Manage. 241, 162-174.

Bagheri, I., Kalbori, S.B., Akef, M., Khormali, F., 2012. Effect of Compaction on Physical and Micromorphological Properties of Forest Soils. Am. J. Plant Sci. 3, 159-163.

Braunack, M.V., 1986. Changes in physical properties of two dry soils during tracked vehicle passage. J. Terramech. 23 (3-4), 141-151.

Bygden, G., Eliasson, L., Wästerlund, I., 2004. Rut depth, soil compaction and rolling resistance when using bogie tracks. J. Terramech. 40, 179-190.

Cajander, A.K., 1949. Forest types and their significance. Acta For. Fenn. 56, 72 pp.

Cambi, M., Certini, G., Neri, F., Marchi, E., 2015. The impact of heavy traffic on forest soils: A review. For. Ecol. Manage. 338, 124-138.

Chamen, T., Alakukku, L., Pires, S., Sommer, C., Spoor, G., Tijink, F., Weisskopf, P., 2003. Prevention strategies for field traffic-induced subsoil compaction: a review. Part 2. Equipment and field practices. Soil Till. Res. 73, 161-174.

Coder, K.D., 2007. Soil Compaction Stress \& Trees: Symptoms, Measures, Treatments. University of Georgia. Warnell School Outreach Monograph WSFNR07-9.

Croke, J., Hairsine, P., Fogarty, P., 2001. Soil recovery from track construction and harvesting changes in surface infiltration, erosion and delivery rates with time. For. Ecol. Manage. 143, 3-12.

Demir, M., Makineci, E., Yilmaz, E., 2007. Investigation of timber harvesting impacts on herbaceous cover, forest floor and surface soil properties on skid road in an oak (Quercus petrea L.) stand. Build. Environ. 42, 1194-1199.

Edlund, J., 2012. Harvesting in the Boreal Forest on Soft Ground - Ways to reduce ground damage. Licentieate thesis at the University of Agricultural Sciences. Umeå.

Eliasson, L., Wästerlund, I., 2007. Effects of slash reinforcement of strip roads on rutting and soil compaction on a moist fine-grained soil. For. Ecol. Manage. 252, 118-123. 
Elliot, W. J., Page-Dumroese, D., Robichaud, P.R., 1999. The Effects of Forest Management on Erosion and Soil Productivity. http://forest.moscowfsl.wsu.edu/smp/docs/docs/Elliot_1-57444-100-0.html (accessed 20.10.2015).

EUA (= Europäische Umweltagentur), 2002. Auf dem Boden der Tatsachen: Bodendegradation und nachhaltige Entwicklung in Europa. Umweltthemen-Serie 16. (in German).

European Commission, 2014. International Year of Soils 2015. A/RES/68/232.

European Commission, 2015. Soil. http://ec.europa.eu/environment/soil/index_en.htm (accessed 31.07.2015).

European Commission, 2016. Soil. http://ec.europa.eu/environment/soil/three_en.htm (accessed 17.08.2017).

Froehlich, H. A., McNabb, D. H., 1983. Minimizing soil compaction in Pacific Northwest forests, in: Stone, E.L. (Eds.), Forest soils and treatment impacts. Proceedings of the Sixth North American Forest Soils Conference, University of Tennessee, Knoxville, pp. 159-192.

Hartanto, H., Prabhu, R., Widayat, A.S.E., Asdak,C., 2003. Factors affecting runoff and soil erosion: plotlevel soil loss monitoring for assessing sustainability of forest management. For. Ecol. Manage. 180, 361374.

HBS (= Heinrich-Böll-Stiftung, Institute for Advanced Sustainability Studies, Bund für Umwelt- und Naturschutz Deutschland \& Le Monde Diplomatique), 2015. Bodenatlas 2015. http://www.boell.de/sites/default/files/bodenatlas2015.pdf (accessed 31.07.2015).

Heiskanen, J., 2003. Maaperän ominaisuudet, in: Mälkönen, E. (Ed.), Metsämaa ja sen hoito, pp. 39-62. (in Finnish).

Heiskanen, J., Tamminen, P., 1992. Maan fysikaalisten ominaisuuksien määrittäminen. Metsäntutkimuslaitoksen tiedonantoja 424. (in Finnish).

Hillel, D., 1982. Introduction to soil physics. Academic press.

Hotanen, J.-P., Nousiainen, H., Mäkipää, R., Reinikainen, A., Tonteri, T., 2008. Metsätyypit - opas kasvupaikkojen luokitteluun. Hämeenlinna (Metsäkustannus Oy). (in Finnish).

Huang, J., Lacey, S.T., Ryan, P.J., 1996. Impact of forest harvesting on the hydraulic properties of surface soil. Soil Sci. 161 (2), 79-86.

Jakobsen, B.F., Greacen, E.L., 1985. Compaction of sandy forest soils by forwarder operations. Soil Till. Res. 5, 55-70. 
Jansson, K.-J., Johansson, J., 1998. Soil changes after traffic with a tracked and a wheeled forest machine: a case study on a silt loam in Sweden. Forestry 71 (1), 57-66.

Klaes, B., Struck, J., Schneider, R., Schüller, G., 2016. Middle-term effects after timber harvesting with heavy machinery on a fine-textured forest soil. Eur. J. For. Res. 135, 1083-1095.

Kremer, J., Schardt, M., 2007. Vergleich der Bogiebänder Eco-Track und Eco-Baltic mit dem Reifen, in: Bayerische Landesanstalt für Wald und Forstwirtschaft: Neue Wege beim Bodenschutz. Waldforschung aktuell 59, 3-5. (in German).

Kremer, J, Wolf, B., Matthies, D. Borchert, H., 2012. Bodenschutz beim Forstmaschineneinsatz. Merkblatt der Bayerischen Landesanstalt für Wald und Forstwirtschaft 22. (in German).

Lenhard, R.J., 1986. Changes in Void Distribution and Volume During Compaction of a Forest Soil. Soil Sci. Soc. Am. J. 50 (2), 462-464.

Lousier, J.D., 1990. Impacts of forest harvesting and regeneration on forest sites. Land Manage. Rep. 67.

Lüscher, P., Frutig, F., Sciacca, S., Spjevak, S., Thees, O., 2010. Physikalischer Bodenschutz im Wald. Merkblatt für die Praxis 45. Birmensdorf (Eldg. Forschungsanstalt WSL). (in German).

Marshall, V.G., 2000. Impacts of forest harvesting on biological processes in northern forest soils. For. Ecol. Manage. 133, 43-60.

Marx, B., Randel, A.C., Schilli, C., Hoeborn, G., Helmus, M., Rinklebe, J., 2013. Ressourcenschutzpotenzial bei Baumaßnahmen bezüglich Boden. Endbericht des Forschungsprogramms „Zukunft Bau“ des Bundesministeriums für Verkehr, Bau und Stadtentwicklung. (in German).

McDonald, T. P., Seixas, F., 1997. Effect of slash on forwarder soil compaction. J. For. Eng. 8 (2), 15-26.

Meyer, C., Lüscher, P., Schulin, R., 2011. Verdichteten Boden mit Schwarzerlen regenerieren? Wald und Holz 10, 40-43. (in German).

Miller, J.H., Sirois, D.L., 1986. Soil Disturbance by Skyline Yarding vs. Skidding in a Loamy Hill Forest. Soil Sci. Soc. Am. J. 50 (6), 1579-1583.

MMM (= Maa- ja metsätalousministeriö), 2014. Valtioneuvoston asetus metsien kestävästä hoidosta ja käytöstä. (in Finnish).

Naghdi, R., Bagheri, I., Akef, M., Mahdavi, A., 2007. Soil compaction caused by 450C Timber Jack wheeled skidder (Shefarood forest, northern Iran). J. For. Sci. 53 (7), 314-319.

Naghdi R., Solgi, A., Ilstedt, U., 2016. Soil chemical and physical properties after skidding by rubber-tired skidder in Hyrcanian forest, Iran. Geoderma 265, 12-18. 
Nugent, C., Kanali, C., Owende, P.M.O., Nieuwenhuis, M., Ward, S., 2003. Characteristic site disturbance due to harvesting and extraction machinery traffic on sensitive forest sites with peat soils. For. Ecol. Manage. $180,85-98$.

Pirinen, P., Simola, H., Aalto, J., Kaukoranta, J.-P., Karlsson, P., Ruuhela, R., 2012. Tilastoja Suomen ilmastosta 1981-2010. Helsinki (Ilmatieteen laitos). (in Finnish).

Rab, M.A., 2004. Recovery of soil physical properties from compaction and soil profile disturbance caused by logging of native forest in Victorian Central Highlands, Australia. For. Ecol. Manage. 191, 329-340.

Rohand, K., Al Kalb, A., Herbauts, J., Verbrugge, J.-C., 2004. Changes in some mechanical properties of a loamy soil under the influence of mechanized forest exploitation in a beech forest of central Belgium. J. Terramech. 40, 235-253.

Sakai, H., Nordfjell, T., Suadicani, K., Talbot, B., Bøllehuus, E., 2008. Soil compaction on forest soils from different kinds of tires and tracks and possibility of accurate estimate. Croatian J. For. Eng. 29 (1), $15-27$. Schoenholz, S.H., Van Miergroet, H., Burger, J.A., 2000. A review of chemical and physical properties as indicators of forest soil quality: challenges and opportunities. For. Ecol. Manage. 138, 335-356.

Shoop, S.A., 1993. Thawing soil strength measurements for predicting vehicle performance. J. Terramech. $30(6), 405-418$.

Sirén M., Ala-Ilomäki, J., Mäkinen, H., Lamminen, S., Mikkola, T., 2013. Harvesting damage caused by thinning of Norway spruce in unfrozen soil. Int. J. For. Eng. 24 (1), 60-75.

Spoor, G., Tijink, F.G.J., Weisskopf, P., 2003. Subsoil compaction: risk, avoidance, identification and alleviation. Soil Till. Res. 73, 175-182.

Surakka, H., Sirén, M., 2007. Poimintahakkuiden puunkorjuun nykytietämys ja tutkimustarpeet. Metsätieteen aikakauskirja 4, 373-390. (in Finnish).

Susnjar M., Horvat, D., Seselj, J., 2006. Soil compaction in timber skidding in winter conditions. Croatian J. For. Eng. 27 (1), 3-15.

Sutherland, B.J., 2003. Preventing soil compaction and rutting in the boreal forest of western Canada. A practical guide to operating timber-harvesting equipment. For. Eng. Res. Inst. Can. Advantage Vol. 4 (7). Uusitalo, J., Ala-Ilomäki, J., 2013. The significance of above-ground biomass, moisture content and mechanical properties of peat layer on the bearing capacity of ditched pine bogs. Silva Fenn. 47 (3), 1-18.

WRB (=World Reference Base for Soil Resources) (2006): A Framework for International Classification, Correlation and Communication: World Soil Resources Reports. 103. (Food and Agriculture Organization). 
546 Wronski, E. B. \& G. Murphy (1994): Responses of Forest Crops to Soil Compaction, in: Soane, B.D., Van

547 Ouwerkerk, C., (Eds.), Soil Compaction in Crop Production. Developments in Agricultural Engineering 11, 548 317-342. Amsterdam (Elsevier).

549 Zeleke, G., Owende, P.M.O., Kanali C.L., Ward, S.M., 2007. Predicting the pressure-sinkage characteristics 550 of two forest sites in Ireland using in situ soil mechanical properties. Biosyst. Eng. 97, 267-281.

551 Äijälä, O., Koistinen, A., Sved, J., Vanhatalo, K., Väisänen P., 2014. Metsänhoidon suositukset. Metsätalou552 den kehittämiskeskus Tapion julkaisuja. (in Finnish). 